\title{
PECULIARITIES OF AMMONIA METABOLISM IN THE LIVER OF RATS UNDER THE CONDITIONS OF DIFFERENT NUTRIENTS CONTENT IN A DIET
}

\author{
G. P. KOPYLCHUK, I. Y. IVANOVICH, O. M. VOLOSHCHUK
}

\author{
Yuriy Fedkovych Chernivtsi National University, \\ Institute of Biology, Chemistry and Natural Resources, Ukraine; \\ e-mail: o.voloschuk@chnu.edu.ua
}

Received: 27 June 2019; Accepted: 15 May 2020

The peculiarities of the metabolic transformations of ammonia in the liver of rats under the conditions of protein deprivation and high content of sucrose in the diet were studied in the research. It has been established that animals kept on high-sucrose (group III) and low-protein/high-sucrose diet (group IV) had hyperammonemia, whereas in rats maintained under the conditions of protein deficiency in the diet (group II) the blood level of ammonia nitrogen was within normal range. The revealed hyperammonemia in animals of the III and IV groups was accompanied by a marked decrease in the activity of mitochondrial enzymes, which provide a replenishment of the endogenous ammonia pool - glutamate dehydrogenase and monoamine oxidase, reaching the minimum values in conditions of the maintenance of animals on the high-sucrose diet. At the same time, there was a marked decrease in the activity of ammonia neutralization enzymes - carbamoyl phosphate synthetase, more significant in animals of the IV group, as well as glutamine synthetase. The obtained results allow us to conclude that the hyperammonemia revealed in animals maintained on the highsucrose diet is not related to the enhanced formation of ammonia, but to the disturbances in the processes of its detoxification in the liver. At the same time, under the conditions of alimentary protein deprivation, a decrease in the activity of the key enzymes of ammonia formation (glutamate dehydrogenase and monoamine oxidase) and neutralization (carbamoyl phosphate synthetase and glutamine synthetase) is probably due to the lack of substrates for these enzymatic reactions. The obtained research results can be used to develop a strategy for correction of the disorders of ammonia metabolism under the conditions of different content of sucrose and protein in diet.

Ke y words: ammonia metabolism, glutamate dehydrogenase, monoamine oxidase, carbamoyl phosphate synthetase, glutamine synthetase, nutrients.

$\mathrm{T}$ o date, despite the relevance of this problem, the question of the possible mechanisms for the formation of various metabolic changes in conditions of the nutritional imbalance remains open [1-3]. Nowadays, it is well-known that the fast-acting carbohydrates and saturated fats are predominant in the diet of people on the background of a deficiency of the full value protein. There are many reasons adults fail to consume enough protein to meet needs - genetic predisposition to low appetite, physiological changes and medical conditions that lead to age- and disease-associated anorexia, physical and mental disabilities that limit shopping and food preparation, and food insecurity due to financial and social limitations [4]. Chronic intake of a high-sucrose diet increases overall energy intake, reduces consumption of food containing more nutritionally adequate calories, and contributes to malnutrition, leading to overweight, obesity, insulin resistance, type 2 diabetes, elevation coronary artery disease, and even cancer [5]. At the same time, it is known that prolonged alimentary protein depriva-

(C) 2020 Kopylchuk G. P. et al. This is an open-access article distributed under the terms of the Creative Commons Attribution License, which permits unrestricted use, distribution, and reproduction in any medium, provided the original author and source are credited. 
tion is accompanied by the disturbances in the metabolic processes, which underlie the development of various pathologies, although their mechanisms remain unexplored [6].

Thus, chronic consumption of the large amounts of sucrose with simultaneous deficiency of protein in the diet may act as a factor of the induction and progression of metabolic disorders, in particular in the liver. The liver plays a critical role in maintaining proper nutrition by regulating the traffic of nutrients; during liver disease, this metabolic balance becomes deregulated, causing numerous nutritional and metabolic complications.

The liver is the major organ responsible for normal $\mathrm{NH}_{4}^{+}$detoxification. There are two pathways involved: periportal hepatocyte conversion of $\mathrm{NH}_{3}$ to urea by the urea-cycle system, and perivenous hepatocyte conversion of $\mathrm{NH}_{4}^{+}$to glutamine by by glutamine synthetase GLS [7]. Ammonia, a highly toxic intermediary metabolite, is formed during the catabolism of the amine groups of amino acids [8]. To prevent ammonia accumulating, it is immediately incorporated into glutamine and reconverted to ammonia in the liver. Here it is rapidly converted into urea by the urea cycle. It is typically a breakdown in the flux through this pathway that leads to hyperammonaemia and though general liver failure.

In this case, the reason for an increase in the blood ammonia level may be caused by either intensification of its formation or disturbances in the ammonia detoxifying function of the liver due to degenerative changes in hepatocytes [9].

The aim of the research was to study the peculiarities of the metabolic transformations of ammonia in the liver of rats under the conditions of protein deprivation and high content of sucrose in the diet.

\section{Materials and Methods}

Experimental design and procedures. In the study, 8-10 week old white nonlinear rats weighing 90-100 g were used. Animals were kept in individual plastic cages with sand bedding; they were fed twice per day having ad libitum access to water. The experiment was conducted in accordance with the rules set by the 'European convention for the protection of vertebrate animals used for experimental and other scientific purposes' (Strasbourg, 1986).

The daily rations were regulated according to principles of pair feeding. The animals were divided into the following experimental groups: I - animals receiving full-value semi-synthetic ration (control group); II - animals receiving low-protein ration; III - animals receiving high-sucrose diet; IV - animals receiving low-protein high-sucrose diet.

The animals of the control group received a standard ration containing 14\% of protein (casein), $10 \%$ of fat, and $76 \%$ of carbohydrates, balanced by all the essential nutrients.

The animals of the group II received isoenergetic ration containing $4.7 \%$ of protein, $10 \%$ of fat, and $85.3 \%$ of carbohydrates, calculated after recommendations of the American Institute of Nutrition [10].

The animals of the group III received high-sucrose diet containing $40 \%$ of sucrose and balanced by all other essential nutrients [11].

The animals of the group IV received isoenergetic ration containing $4.7 \%$ of protein, $40 \%$ of sucrose and balanced by all other essential nutrients.

The animals were maintained on the corresponding diet during four weeks. Cervical dislocation was performed under the light ether anesthesia on day 29 of the experiment.

Mitochondrial fraction of the liver homogenate was separated by differential centrifugation (Heraeus Biofuge, Germany) in the following buffer medium: $250 \mathrm{mM}$ sucrose, $1 \mathrm{mM}$ EDTA, $10 \mathrm{mM}$ Tris-HCl; $\mathrm{pH} 7.4$ at $0-3{ }^{\circ} \mathrm{C}$.

Enzyme assays. Glutamate dehydrogenase activity was estimated by changes in NADH amount equimolar to glutamate concentration used in the reaction. A decrease in NADH content was measured spectrophotometrically at $\lambda=340 \mathrm{~nm}$ [12]. Glutamate dehydrogenase activity was expressed in nmol $\mathrm{NADH} /(\min \times \operatorname{mg}$ protein).

Carbamoyl phosphate synthetase I activity in intact mitochondria was measured at $30{ }^{\circ} \mathrm{C}$ using the following incubation conditions: $\mathrm{NH}_{4} \mathrm{Cl}, 10 \mathrm{mM}$; $\mathrm{KHCO}_{3} 20 \mathrm{mM}$; ornithine, $10 \mathrm{mM}$; phosphate, $5 \mathrm{mM}$; Tris, $50 \mathrm{mM}$; ATP, $5 \mathrm{mM}$; KCl, $50 \mathrm{mM}$; carbonyl cyanide p-trifluorophenylhydrazone, $1.0 \mathrm{mM}$; and oligomycin, $5 \mathrm{mg} / \mathrm{ml}$. Final $\mathrm{pH}$ was 7.2. Incubation was carried out in a volume of $1000 \mu$. The reaction was commenced by the addition of mitochondria, $100 \mu \mathrm{l}$, as a 5 to $10 \mathrm{mg} / \mathrm{ml}$ suspension in preparative medium. The reaction was terminated after 12 min by the addition of an equal volume of $10 \%$ trichloroacetic acid solution. After centrifugation, citrulline formation was determined in the supernatant [13]. Activity of carbamoyl phosphate synthetase I was calculated as nanomoles of citrulline formed $\mathrm{min} / \mathrm{mg}$ of mitochondrial protein [14]. 
Glutamine synthetase activity was determined by measurement of the inorganic phosphate released in reaction mixtures containing ammonia [15]. The assay mixtures $(0.5 \mathrm{ml})$ usually contained imidazole-HCl buffer (0.1 M pH 7.2), 2-mercaptoethanol ( $25 \mathrm{mM})$, L-glutamate (50 mM; pH 7.2), ATP (10 mM), $\mathrm{MgCl}_{2}(20 \mathrm{mM})$, and $\mathrm{NH}_{2} \mathrm{OH}(125 \mathrm{mM})$ or $\mathrm{NH}_{4} \mathrm{Cl}(40 \mathrm{mM})$. Inorganic phosphate was determined by the methods of Fiske and Subbarow.

Monoamine oxidase activity was routinely measured, with benzylamine as substrate, by the spectrophotometric method [16]. In this standard assay, I unit of enzymatic activity was defined as the amount of enzyme catalyzing a change in absorbance at $250 \mathrm{~nm}$ per min at $25^{\circ}$ in $3.0 \mathrm{ml}$ reaction mixtures containing $3.3 \mathrm{mM}$ buffered benzylamine and $0.20 \mathrm{M}$ phosphate buffer, $\mathrm{pH}$ 7.2.

The diffused ammonia was determined using a Nessler's solution. Absorbancies were measured at $415 \mathrm{~nm}$ with the use of a spectrophotometer [17]. The solutions were boiled for 15 min to remove traces of volatile Nessler-reactive material.

Protein determination. The protein content was determined according to the method of Lowry et al [18].

Data analysis and statistics. The data were compared and analyzed by using unpaired T-test. Characteristics of the study group were expressed as Mean \pm Standart Deviation for normal distribution. For all statistical calculations, significance was considered to be a value of $P<0.05$.

\section{Results and Discussion}

It was established in our studies that the level of ammonia in the blood serum of animals from groups III and IV was twice as high as control (Fig. 1). At the same time, in conditions of the lack of protein in the diet of animals, the amount of ammonia nitrogen in the blood serum (group II) remains at the control level (Fig. 1).

The established hyperammonemia in animals from the III and IV groups poses a significant danger to the body. Ammonia in solution is composed of a gas $\left(\mathrm{NH}_{3}\right)$ and an ionic $\left(\mathrm{NH}_{4}^{+}\right)$component which are both capable of crossing plasma membranes through diffusion, channels and transport mechanisms and as a result have a direct effect on $\mathrm{pH}$ [19]. Hyperammonemia promotes the development of metabolic alkalosis, and consequently, the affinity of haemoglobin to oxygen increases, which leads to tissue hypoxia.

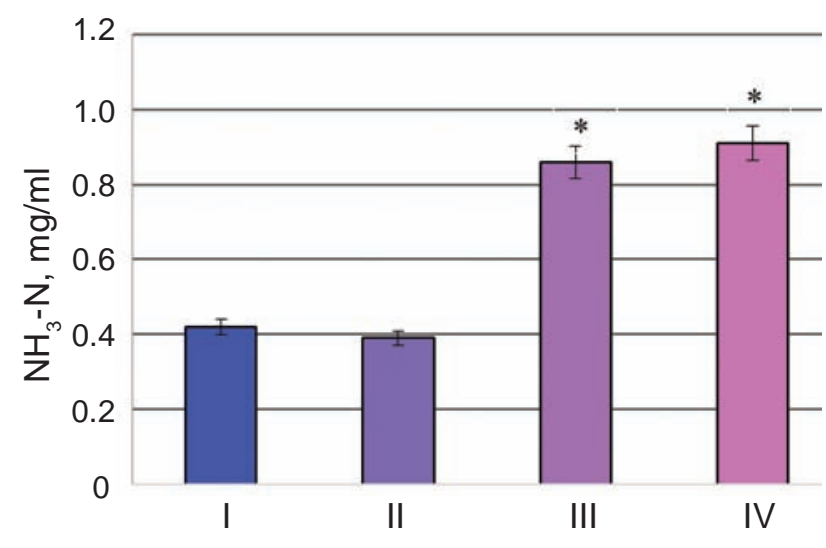

Fig. 1. The content of ammonia in blood serum of rats under the conditions of different nutrients content in a diet: I-animals receiving complete semi-synthetic ration; II - animals receiving low-protein ration; III - animals receiving high-sucrose diet; IV - animals receiving low-protein high-sucrose diet. *Significantly different from the control, $P \leq 0.05$

Furthermore, $\left(\mathrm{NH}_{4}^{+}\right)$has similar properties as $\mathrm{K}^{+}$and, therefore, competes with $\mathrm{K}^{+}$on $\mathrm{K}^{+}$transporters and channels resulting in a direct effect on membrane potential. In hyperammonemia, blood ammonia is transported to the brain through the blood-brain barrier. These direct effects of elevated ammonia concentrations on the brain will lead to a cascade of secondary effects and encephalopathy [20].

Liver is the usual and chief site of removing excess ammonia from the body through its conversion into urea [21]. Liver is the chief organ of scavenging ammonia from the body, hyperammonemia will quickly develop, when liver fails.

The possible causes of revealed hyperammonemia in experimental animals from groups III and IV can be enhanced formation of ammonia in the liver or disturbances of its conversion into urea.

In quantitative ratio, the main source of ammonia in the body is the oxidative deamination of amino acids with its key enzyme glutamate dehydrogenase [22]. Besides, reactions of the deamination of biogenic amines with the participation of mitochondrial monoamine oxidase also make a significant contribution to the replenishment of the endogenous ammonia pool [23]. Thus, glutamate dehydrogenase and monoamine oxidase reactions can be considered as the main biochemical mechanisms of ammonia formation in the organism. 
In animals from the group II, any changes in the blood ammonia level were not revealed (Fig. 1), but we established an inhibition of the processes of its formation in the liver, verified by a significant decrease in glutamate dehydrogenase (Fig. 2) and monoamine oxidase activity (Fig. 3). Obviously, these changes are due to a deficiency of free amino acids in the body caused by the insufficient intake of exogenous protein.

Hyperammonemia in conditions of high-sucrose diet (group III, Fig. 1) is accompanied by the maximum reduction in the activity of the studied mitochondrial enzymes - glutamate dehydrogenase and monoamine oxidase in 1.8 and 2.5 times, respectively (Fig. 2, 3).

The literature data [24] shows the relationship between high levels of sucrose in the diet and the degree of degenerative changes in the liver.

Lipids, which synthesis in hepatocytes is intensified under these conditions, serve as ligands for immune receptors and thus can initiate an immune response, causing an increase in the content of inflammatory cytokines. Hepatic and systemic inflammatory cytokines (TNF- $\alpha$, IL-6) that initiate the onset of inflammation in the liver tissue are considered as a key factor of damage in conditions of the high-sucrose diet.

Destructive changes in hepatocytes manifest by the appearance of edematous cells with excessive

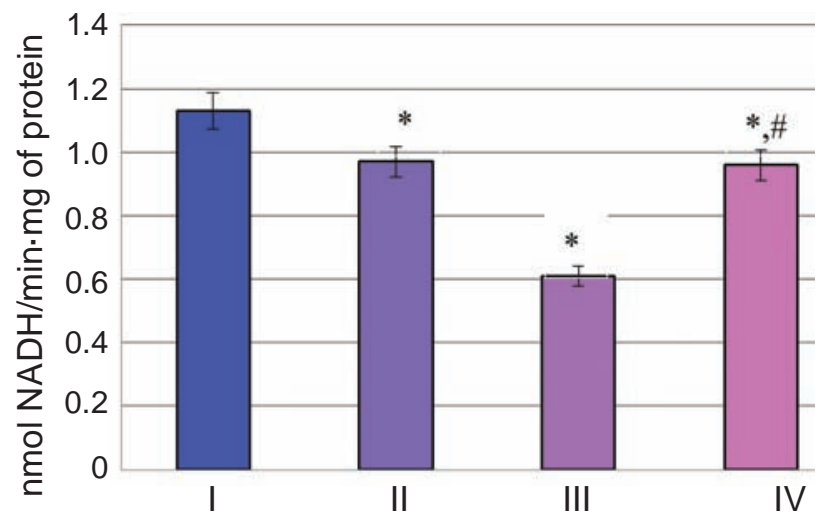

Fig. 2. Glutamate dehydrogenases activity in the rat liver mitochondrial fraction under the conditions of different nutrients content in a diet: I-animals receiving complete semi-synthetic ration; II - animals receiving low-protein ration; III - animals receiving high-sucrose diet; IV - animals receiving low-protein high-sucrose diet. *Significantly different from the control, $P \leq 0.05$; " significantly different from the group III, $P \leq 0.05$ lipid drops in the cytoplasm, swelling of nuclei and mitochondria, infiltration of liver tissues by leukocytes and formation of the inflammatory focus.

In addition, under the conditions of the highsucrose diet, the process of free radical oxidation of biomolecules is intensified [25], which is considered as an additional damaging mechanism of hepatocytes.

Thus, established hyperammonemia in conditions of the high-sucrose diet is not associated with the enhanced formation of ammonia.

Therefore, our next step was to study the activity of the key enzymes of the ammonia neutralization in the organism - carbamoyl phosphate synthetase and glutamine synthetase.

We have found that in the group of animals maintained on the high-sucrose diet (group III), a two-fold reduction in the activity of carbamoyl phosphate synthetase is registered compared to the control parameters (Fig. 4). Since this enzyme is considere as a regulatory, it is obvious that the decrease in the activity of carbamoyl phosphate synthetase indicates an inhibition of the urea cycle reactions [26].

At the same time, under the conditions of the high-sucrose diet (Fig. 5, group III) there was a 2-fold decrease in glutamine synthetase activity in the liver cells.

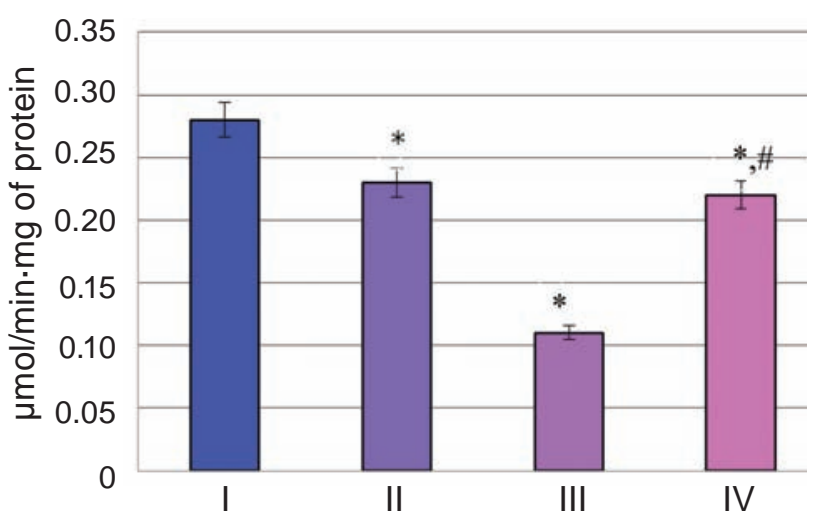

Fig. 3. Monoamine oxidase activity in the rat liver mitochondrial fraction under the conditions of different nutrients content in a diet: I - animals receiving complete semi-synthetic ration; II - animals receiving low-protein ration; III - animals receiving high-sucrose diet; IV - animals receiving low-protein high-sucrose diet. *Significantly different from the control, $P \leq 0.05$; ${ }^{*}$ significantly different from the group III, $P \leq 0.05$ 


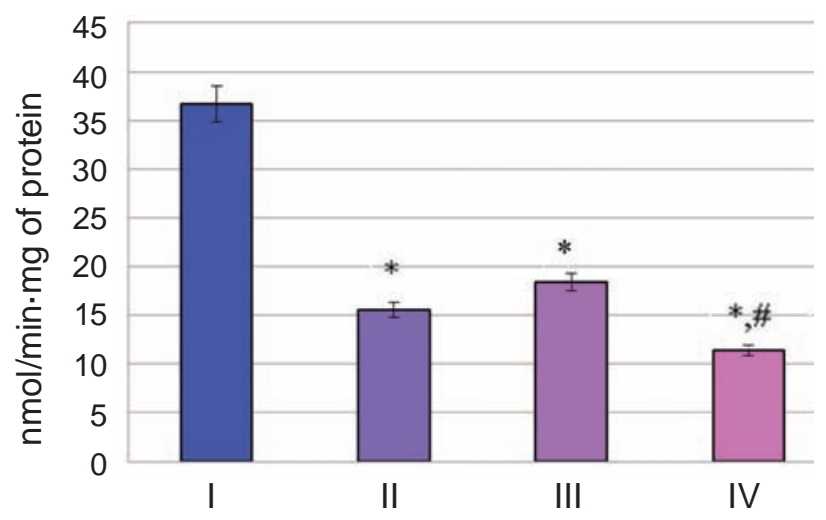

Fig. 4. Carbamoyl phosphate synthetase I activity in the rat liver mitochondrial fraction under the conditions of different nutrients content in a diet: I animals receiving complete semi-synthetic ration; II - animals receiving low-protein ration; III - animals receiving high-sucrose diet; IV - animals receiving low-protein high-sucrose diet. *Significantly different from the control, $P \leq 0.05$; " significantly different from the group III, $P \leq 0.05$

Glutamine synthetase, another important ammonia-removing pathway located in the liver, catalyzes the amidation of glutamate into glutamine, thereby removing an ammonia molecule. This highaffinity, low-capacity reaction takes place in the perivenous hepatocytes located around the hepatic vein and acts as a scavenger for the ammonia that escapes periportal urea synthesis. However, during liver injury, given the reduced hepatic capacity for ammonia removal, the extrahepatic interorgan ammonia metabolism is altered (including glutamine metabolism), thus upsetting the balance between ammonia-producing/removing organs and ammonia homeostasis [27].

Consequently, the obtained results allow us to conclude that discovered hyperammonemia in the conditions of the maintenance of animals on the high-sucrose diet is not related to the enhanced formation of ammonia, but to the disturbances in the processes of its detoxification in the liver.

Simultaneously, under the conditions of alimentary protein deprivation, the decrease in the activity of the investigated key enzymes of ammonia formation (glutamate dehydrogenase and monoamine oxidase) and neutralization (carbamoyl phosphate synthetase and glutamine synthetase) is probably due to the lack of substrates for these enzymatic reactions.

As for the group IV of animals, which were kept on the protein-deficient diet with the high su-

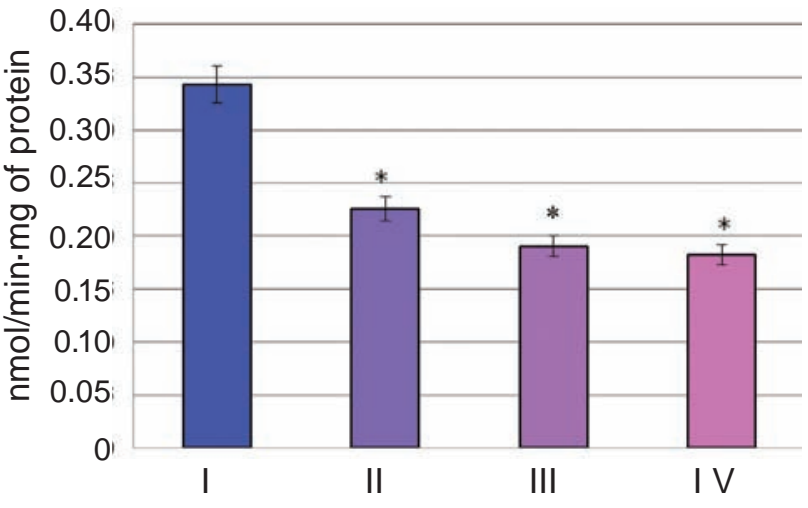

Fig. 5. Glutamine synthetase activity in the rat liver mitochondrial fraction under the conditions of different nutrients content in a diet: I-animals receiving complete semi-synthetic ration; II - animals receiving low-protein ration; III - animals receiving high-sucrose diet; IV - animals receiving low-protein high-sucrose diet. *Significantly different from the control, $P \leq 0.05$

crose content, the established hyperammonemia (Fig. 1) was accompanied by a decrease in the activity of the key enzymes of ammonia formation to the level of those indicators in animals with the alimentary protein deficiency without hyperammonemia (Fig. 2, 3, group II).

In addition, in animals from this group, the activity of carbamoyl phosphate synthetase was decreased by 3 times compared to the control, reaching minimum absolute values in comparison with other experimental groups (Fig. 4), which indicates a significant worsening of disturbances of the urea cycle.

At the same time, the level of glutamine synthetase activity did not differ from the enzyme activity in the group of animals that were kept on a high-sucrose diet (group III, Fig. 5).

Therefore, the main determinant for the development of hyperammonemia under the conditions of the simultaneous imbalance of the two main nutrients (protein and sucrose) is the maximum reduction in the activity of the key regulatory enzyme of the urea cycle - carbamoyl phosphate synthetase.

The obtained results can be used to develop a strategy for the correction of ammonia metabolism disorders under the conditions of different content of sucrose and protein in the diet.

The work was done within framework of the "Biochemical and laser-polarimetric parameters of complex forecasting of metabolic disturbances" program, State Register No 0119U100717. 
Conflict of interest. Authors have completed the Unified Conflicts of Interest form at http://ukrbiochemjournal.org/wp-content/uploads/2018/12/ coi_disclosure.pdf and declare no conflict of interest.

\section{ОСОБЛИВОСТІ МЕТАБОЛІЗМУ АМІАКУ В ПЕЧІНЦІ ЩУ РІВ ЗА РІЗНОЇ ЗАБЕЗПЕЧЕНОСТІ ХАРЧОВОГО РАЦІОНУ НУТРІЕНТАМИ}

\section{Г. П. Копильчук, І. Ю. Іванович, О. М. Волошук}

\author{
Чернівецький національний університет \\ імені Юрія Федьковича, Україна, Інститут \\ біології, хімії та біоресурсів; \\ e-mail: o.voloschuk@chnu.edu.ua
}

У роботі досліджували особливості метаболічних перетворень аміаку в печінці щурів в умовах депривації протеїну та високого вмісту сахарози в харчовому раціоні. Встановлено, що для тварин, які утримувалися на високосахарозному (група III) та низькопротеїновому/високосахарозному раціоні (група IV), характерна гіперамоніємія, тоді як в умовах нестачі протеїну в харчовому раціоні (група II) кількість азоту аміаку в сироватці крові зберігалася на рівні контрольних значень. Виявлена гіперамоніємія в тварин III i IV групи супроводжувалася вираженим зниженням активності мітохондріальних ензимів, які забезпечують поповнення пулу ендогенного аміаку, - глутаматдегідрогенази та моноамінооксидази. У тварин цих груп також встановлено зниження активності ензимів знешкодження аміаку - карбамоїлфосфатсинтетази (максимально виражене в тварин IV групи) і глутамінсинтетази. Одержані результати дозволяють дійти висновку, що виявлена нами гіперамоніємія, в умовах утримання тварин на високосахарозній дієті, пов'язана не з посиленим утворенням аміаку, а з порушенням процесів його детоксикації в печінці. Водночас в умовах аліментарної депривації протеїну показано зниження активності ключових ензимів утворення (глутаматдегідрогенази i моноамінооксидази) та знешкодження (карбамоїлфосфатсинтетази і глутамінсинтетази) аміаку. Це, ймовірно, пов'язано з дефіцитом субстратів для зазначених ензиматичних реакцій. Результати досліджень можуть бути використані для розробки методу корекції порушень обміну аміаку в умовах різної забезпеченості раціону сахарозою та протеїном.

К лю ю о і слов а: метаболізм аміаку, глутаматдегідрогеназа, моноамінооксидаза, карбамоїлфосфатсинтетаза, глутамінсинтетаза, нутрієнти.

\section{References}

1. Wu G. Dietary protein intake and human health. Food Funct. 2016; 7(3): 1251-1265.

2. Tikole RV, Kulkarni R, Shailaja U, Nithin SA, Mallanvar V, Nayankumar S, Tikole YV. Nutritional deficiency disorders in paediatrics: an ayurvedic perspective. Int $J$ Res Ayurveda Pharm. 2013; 4(4): 605-607.

3. Malta A, de Oliveira JC, da Silva Ribeiro TA, Tófolo LP, Barella LF, Prates KV, Miranda RA, Elmhiri G, da Silva Franco CC, Agostinho AR, Trombini AB, Pavanello A, Gravena C, Abdennebi-Najar L, de Freitas Mathias PC. Low-protein diet in adult male rats has longterm effects on metabolism. J Endocrinol. 2014; 221(2): 285-295.

4. Deutz NEP, Bauer JM, Barazzoni R, Biolo G, Boirie Y, Bosy-Westphal A, Cederholm T, Cruz-Jentoft A, Krznariç Z, Nair KS, Singer P, Teta D, Tipton K, Calder PC. Protein intake and exercise for optimal muscle function with aging: recommendations from the ESPEN expert group. Clin Nutr. 2014; 33(6): 929-936.

5. Maciejczyk M, Matczuk J, ŻendzianPiotrowska M, Niklińska W, Fejfer K, Szarmach I, Ładny JR, Zieniewska I, Zalewska A. Eightweek consumption of high-sucrose diet has a pro-oxidant effect and alters the function of the salivary glands of rats. Nutrients. 2018; 10(10): 1-19.

6. Pezeshki A, Zapata RC, Singh A, Yee NJ, Chelikani PK. Low protein diets produce divergent effects on energy balance. Sci Rep. 2016; 6: 1-16.

7. Levitt DG, Levitt MD. A model of bloodammonia homeostasis based on a quantitative analysis of nitrogen metabolism in the multiple organs involved in the production, catabolism, and excretion of ammonia in humans. Clin Exp Gastroenterol. 2018; 11: 193-215. 
8. Broomfield A, Grunewald S. How to use serum ammonia. Arch Dis Child Educ Pract Ed. 2012; 97(2): 72-77.

9. Tapper EB, Jiang ZG, Patwardhan VR. Refining the ammonia hypothesis: a physiologydriven approach to the treatment of hepatic encephalopathy. Mayo Clin Proc. 2015; 90(5): 646-658.

10. Reeves PG, Nielsen FH, Fahey GC Jr. AIN-93 purified diets for laboratory rodents: final report of the American Institute of Nutrition ad hoc writing committee on the reformulation of the AIN-76A rodent. J Nutr. 1993; 123(11): 19391951.

11. Fernandes-Lima F, Monte TL, Nascimento FA, Gregório BM. Short exposure to a high-sucrose diet and the first 'hit' of nonalcoholic fatty liver disease in mice. Cells Tissues Organs. 2016; 201(6): 464-472.

12. Voloshchuk ON, Marchenko MM. Effects of LowDose Radiation on Glutamate Dehydrogenase Activity in Tissues of Rats with Transplanted Guerin's Carcinoma. Bull Exp Biol Med. 2013; 156(1): 91-93.

13. Avagyan HKh, Alchujyan NKh, Movsesyan NH, Aghababova AA, Movsesyan HA, Hovhannisyan MR, Barseghyan KA, Kevorkian GA. Subcellular metabolism peculiarities and effect of bacterial therapy in Ehrlich ascites carcinoma: arginine. Med Sci Armenia. 2013; 53(2): 22-33.

14. Stewart PM, Walser M. Short term regulation of ureagenesis. J Biol Chem. 1980; 255(11): 52705280.

15. Tate SS, Leu FY, Meister A. Rat Liver Glutamine Synthetase. Preparation, Properties, and Mechanism of Inhibition by Carbamyl Phosphate. J Biol Chem. 1972; 247(17): 53125321.

16. McEwen CM Jr, Sasaki G, Lenz WR Jr. Human Liver Mitochondrial Monoamine Oxidase. I. Kinetic Studies of Model Interactions. J Biol Chem. 1968; 243(20): 5217-5225.
17. Reinhold JG, Chung CC. Formation of artifactual ammonia in blood by action of alkali: its significance for the measurement of blood ammonia. Clin Chem. 1961; 7(1): 54-69.

18. Lowry OH, Rosebrough NJ, Farr AL, Randall RJ. Protein measurement with the Folin phenol reagent. J Biol Chem. 1951; 193(1): 265-275.

19. Jaeschke H, Mullen K, Moradpour D. Blood ammonia determination in cirrhosis: still confusing after all these years? Hepatology. 2003; 38(5): 1307-1310.

20. Bosoi CR, Rose CF. Identifying the direct effects of ammonia on the brain. Metab Brain Dis. 2009; 24(1): 95-102.

21. Khan WM, Badshah A, Haider I, Khan A, Ajmal F. Association of serum ammonia levels with grades of hepatic encephalopathy in patients with decompensated chronic liver disease. J Med Sci. 2017; 25(4): 421-424.

22. Karaca M, Martin-Levilain J, Grimaldi M, Li L, Dizin E, Emre Y, Maechler P. Liver glutamate dehydrogenase controls whole body energy partitioning through amino acid-derived gluconeogenesis and ammonia homeostasis. Diabetes. 2018; 67(10): 1949-1961.

23. Kosenko E., Yury Kaminsky Y. Brain monoamine oxidase $\mathrm{A}$ in hyperammonemia is regulated by NMDA receptors. Cent Eur J Biol. 2009; 4(3): 321-326.

24. Morsy M. Impact of different doses of sucrose on the liver function and ultrastructure in rats. Med J Cairo Univ. 2014; 82(1): 133-144.

25. Prasad K, Dhar I. Oxidative stress as a mechanism of added sugar-induced cardiovascular disease. Int J Angiol. 2014; 23(4): 217-226.

26. Chen Z., Tang N., Wang X., Chen Y. The activity of the carbamoyl phosphate synthase 1 promoter in human liver-derived cells is dependent on hepatocyte nuclear factor 3-beta. J Cell Mol Med. 2017; 21(9): 2036-2045.

27. Rose CF. Ammonia-lowering strategies for the treatment of hepatic encephalopathy. Clin Pharmacol Ther. 2012; 92(3): 321-331. 